\title{
UMIEJSCOWIENIE KONTROLI RODZICIELSKIEJ MATEK A ICH WSPÓŁPRACA ZE SPECJALISTAMI W PROCESIE TERAPII DZIECI Z OPÓŹNIENIEM ROZWOJU PSYCHORUCHOWEGO
}

Streszczenie: Celem przeprowadzonych badań było udzielenie odpowiedzi na pytanie o lokalizację kontroli wychowawczej matek dzieci z opóźnieniem rozwoju psychoruchowego, które podejmowały współpracę w procesie wczesnej interwencji oraz matek, które wykazywały trudności w podejmowaniu działań rehabilitacyjnych i współdziałaniu ze specjalistami. W wyniku przeprowadzonych badań stwierdzono, że matki, które mają trudności w podejmowaniu współpracy w procesie wczesnego wspomagania rozwoju dziecka, mają większe nasilenie zewnętrznego umiejscowienia kontroli niż matki, które nawiązują dobrą współpracę ze specjalistami i angażują się w proces pomocowy.

Słowa kluczowe: umiejscowienie kontroli rodzicielskiej, współpraca rodziców i terapeutów, zaburzenia rozwoju psychoruchowego.

\section{Wprowadzenie}

Dzieci z opóźnieniem rozwoju psychoruchowego i ich rodzice objęci są systemem wczesnej interwencji w ramach służby zdrowia, a także wczesnego wspomagania rozwoju w placówkach oświatowych. Biorąc pod uwagę fakt, że małe dziecko rozwija się w obrębie mikrosystemu, który tworzy głównie najbliższa rodzina, oddziaływania pomocowe wymagają ścisłej współpracy pomiędzy specjalistami a jego rodzicami. Według założeń teorii systemowej rodzina stanowi system psychospołeczny o określonej strukturze, wzorach funkcjonowania, podlegający ciągłym zmianom związanym zarówno z naturalnymi procesami rozwojowymi, jak również z różnego rodzaju losowymi zdarzeniami (Józefik 2012). Przyjmując, że rodzina jest głównym czynnikiem warunkującym rozwój człowieka i miejscem, gdzie dziecko wchodząc w relacje z najbliższymi - rodzicami, rodzeństwem czy 
dalszą rodziną, doświadcza podstawowych interakcji międzyludzkich (Orwid 2012), należy założyć, że bez odpowiedniego wsparcia rodziny nie można prowadzić efektywnego procesu terapeutycznego. Podstawowym warunkiem skuteczności pomocy jest współpraca środowiska terapeutycznego i rodzinnego. Współpraca ta nie zawsze układa się w pozytywny sposób, co często wiąże się z odmiennymi oczekiwaniami i możliwościami obu stron (Kielin 2003). Udzielanie wsparcia dostosowanego do potrzeb wymaga przeprowadzenia wnikliwej diagnozy samego podopiecznego, a także oceny funkcjonowania jego rodziny. Konieczne jest więc poszukiwanie czynników, które sprzyjają współpracy oraz tych, które ją utrudniają.

\section{Współpraca specjalistów i rodziców w kontekście funkcjonowania rodziny z dzieckiem $\mathrm{z}$ niepełnosprawnością}

Rodzice dzieci z niepełnosprawnością są ważnym ogniwem procesu terapeutycznego i chociaż w literaturze przedmiotu ich rola jest różnie postrzegana, zarówno przez terapeutów, jak i przez samych rodziców (Lew-Koralewicz 2013), to nawiązanie dobrej współpracy ze środowiskiem rodzinnym warunkuje efektywność procesu terapeutycznego.

Współpraca definiowana jest przez Wincentego Okonia (2001, s. 443) jako „współdziałanie ze sobą jednostek lub grup ludzi, wykonujących swoje cząstkowe zadania, aby osiągnąć jakiś wspólny cel”. Wymieniony autor zakłada, że współpraca wymaga wzajemnego zaufania i lojalności, a także podporządkowania się przyjętemu celowi.

Biorąc pod uwagę fakt, że wiadomość o niepełnosprawności dziecka jest traumatycznym i zmieniającym życie wydarzeniem, współpraca z rodzicami, w zależności od ich kondycji psychicznej, może układać się w różny sposób. Sytuacja niepełnosprawności u syna lub córki generuje konieczność przystosowania się do problemów dziecka, co wiąże się z przechodzeniem przez kolejne fazy zmagania się z kryzysem.

Milton Seligman (1999), opierając się na podziale Elisabeth Kubler-Ross, opisuje pięć etapów żałoby (rozumianej jako stan psychiczny rodziców, który powstaje po stracie dziecka wymarzonego w konfrontacji z urodzonym [Kościelska 1998, s. 52]), przez które przechodzą rodzice po otrzymaniu diagnozy o niepełnosprawności dziecka. Pierwszym etapem jest wypieranie problemu i szok. Rodzice często poszukują alternatywnych diagnoz, nie godzą się z postawionym rozpoznaniem. Towarzyszy im poczucie bezsilności, dezorganizacji, zamętu, co powoduje, że trudno im racjonalnie myśleć i przyjmować informacje. Kolejną fazę - targowania się - cechuje myślenie fantastyczne, magiczne. Może być to zwrócenie się w stronę religii i oczekiwanie na cud lub różnego rodzaju pertraktacje, np. zakładanie, że jeśli podejmie się ciężką pracę lub będzie się pomocnym dla innych, to stan dziecka znacząco się poprawi. Brak oczekiwanych efektów wiąże się z wystąpieniem fazy złości, agresji. Rodzice zadają sobie pytanie: „Dlaczego ja?”, obwiniają otoczenie, 
najczęściej specjalistów o brak wystarczających efektów terapii. Niekiedy winą za stan dziecka obarczają samych siebie. $Z$ czasem rodzice zdają sobie sprawę, że ta postawa nie przyczynia się do poprawy sytuacji dziecka i nie sprzyja funkcjonowaniu rodziny. W kolejnym etapie może pojawić się depresja o charakterze przejściowym lub trwałym, jako naturalna odpowiedź na doświadczanie chronicznego stresu. Rodzicom na tym etapie towarzyszy smutek i poczucie utraty sensu życia. W ostatnim etapie - akceptacji - rodzice zaczynają realnie oceniać możliwości dziecka, wspierać jego niezależność, zajmować się nim bez poczucia winy i czerpać radość $\mathrm{z}$ tego kontaktu. Jest to również czas, w którym rodzice mogą podejmować efektywną współpracę z profesjonalistami i tworzyć realistyczne krótko- i długoterminowe plany, dotyczące dziecka, jego terapii i przyszłości.

Efektywna współpraca pojawia się więc dopiero na etapie akceptacji, co nie oznacza, że rodzice we wcześniejszych fazach kryzysu mogą być pozostawieni sami sobie. Rodzina dziecka $z$ dysfunkcjami rozwojowymi powinna zostać otoczona wsparciem i pomocą od momentu rozpoznania problemu, stąd ważne jest poznawanie środowiska rodzinnego podopiecznych w celu odpowiedzi na specyficzne potrzeby poszczególnych rodzin. Rolą specjalistów od wczesnej interwencji i wczesnego wspomagania rozwoju jest wnikliwa diagnoza środowiska rodzinnego, a w szczególności jego potrzeb, możliwości, a także niekiedy ograniczeń. Pozwoli to na optymalizowanie oddziaływań pomocowych i dostosowanie ich do realnych potrzeb i zasobów danej rodziny. Zróżnicowane potrzeby wynikające zarówno z rodzaju niepełnosprawności dziecka, jak również zasobów poszczególnych rodzin, określają warunki współpracy.

Stanisław Kawula, analizując stosunki pomiędzy rodzicami a środowiskiem szkolnym, wskazuje na cztery typy relacji: partycypację, akomodację, inercję i opozycję (Kawula, Brągiel, Janke 1997). Przenosząc podział Kawuli na grunt współpracy z rodzicami w ramach wspomagania rozwoju dziecka, partycypację będziemy rozumieć tutaj jako współudział i współpracę rodziców w procesie terapeutycznym, polegającą na aktywnym angażowaniu się w planowanie i realizowanie działań terapeutycznych wobec dziecka. Współpraca ta charakteryzuje się aktywnym poszukiwaniem rozwiązań i wzajemnym inspirującym stosunkiem do procesu pomocowego. Akomodacja z kolei to pozytywne ustosunkowanie się rodziców do stawianych przez terapeutów wymagań i realizacja proponowanych zadań, bez przejawiania własnej inicjatywy. Rodzice wykonują proponowane zalecenia i pozytywnie odnoszą się do przedstawianych przez terapeutów rozwiązań. Inercja stanowi niekorzystny dla procesu terapeutycznego typ relacji. Rodzina $\mathrm{w}$ tym przypadku pozostaje bierna i nie angażuje się w proponowane działania terapeutyczne, a rodzice ignorują inicjatywy i prośby terapeutów. Rodziny, które charakteryzuje postawa opozycyjna, są bardzo trudnymi partnerami do współpracy, gdyż często odrzucają proponowane rozwiązania pomocowe, a niekiedy pozostają w konflikcie ze specjalistami. Postawa opozycyjna uniemożliwia efektywną pomoc dziecku. 
Aby dobrze zaplanować proces wspierania rodziny, należy rozpoznać środowisko rodzinne, z którym będziemy współpracować na różnych płaszczyznach. Kawula (1997) wskazuje na trzy główne grupy czynników: ekonomiczno-społeczne, kulturalne i psychopedagogiczne.

\section{Lokalizacja kontroli rodzicielskiej a podejmowanie działań terapeutycznych}

Jednym z psychopedagogicznych czynników, który może wpływać na proces współpracy pomiędzy rodzicami i terapeutami, jest lokalizacja kontroli rodzicielskiej. Teoria lokalizacji kontroli została opracowana przez Juliana Rottera i określa ogólne przekonania o możliwości kontrolowania skutków własnego postępowania. Rotter zakłada, że człowiek działa w sytuacjach, które można podzielić na takie, kiedy sprawuje kontrolę nad rezultatami oraz takie, gdy wynik działania jest zależny od innych ludzi lub czynników losowych. W trakcie rozwoju, w wyniku różnych sytuacji życiowych, człowiek wyrabia sobie uogólnione oczekiwania dotyczące związków jego zachowania ze skutkami tych zachowań (Szmigielska 1999). Osoby o wewnętrznym umiejscowieniu kontroli są przekonane, że ponoszą odpowiedzialność za to, co im się przydarza, same decydują o własnym życiu (Tavris, Wade 1999). $Z$ poczuciem kontroli wewnętrznej wiążą się takie zmienne, jak wiara w siebie, wysoka samoocena, odporność na frustrację, większa samodzielność i niezależność w działaniu, a także większa motywacja do działania i wytrwałość (Sęk 200o). Barbara Szmigielska (1999) podkreśla ponadto, że osoby o wewnętrznym umiejscowieniu kontroli są odpowiedzialne i sumienne w wykonywaniu zadań oraz chętne do współpracy i współdziałania. Osoby o zewnętrznym poczuciu kontroli uważają, że ich życiem rządzi los, przypadek lub inni ludzie. Mają one tendencje do obniżonej samooceny, słabej wiary we własne możliwości. Często osoby te przekonane są o niewielkim wpływie na przebieg wydarzeń, mają tendencję do rezygnowania $z$ angażowania się i do unikania sytuacji trudnych, co również pozwala nie przyjmować odpowiedzialności za ewentualną porażkę (Sęk 200o). Osoby o zewnętrznym umiejscowieniu kontroli mogą czuć się bezradne wobec dotyczących ich zdarzeń oraz zakładać, że podejmowane przez nich działania nie mają większego znaczenia (Pervin 2002).

Przenosząc założenia teorii Rottera na grunt rodziny, możemy odnieść je do funkcjonowania rodziców $\mathrm{w}$ różnych obszarach życia, a przede wszystkim w rolach rodzicielskich. Leslie Campis, Robert Lyman i Steven Prentice-Dunn (1986) odnieśli teorię ogólnej lokalizacji kontroli do sytuacji wychowawczych i założyli, że umiejscowienie kontroli rodzicielskiej jest miarą nasilenia sytuacji, w jakiej rodzice zakładają, że zachowanie ich dziecka jest kontrolowane przez ich własne oddziaływania wychowawcze, czy też jest zależne od zewnętrznych czynników, na które oni nie mają wpływu. Badania lokalizacji kontroli rodzicielskiej (m.in. Hassall i in. 2005, Freed Thompson 2011) wskazują na to, że zewnętrzna lokalizacja kontroli związana jest z częstszym występowaniem zachowań problemowych u dzieci, nasileniem 
depresji u matek, niższym poziomem wykształcenia matek, trudniejszą sytuacją materialną, wiekiem matki, a także z niższym poczuciem własnej skuteczności.

Zagadnienie lokalizacji kontroli rodzicielskiej może stanowić istotny czynnik warunkujący podejmowanie współpracy ze specjalistami w procesie wspomagania rozwoju dziecka. Odnosząc się do przedstawionych wyników badań, można założyć, że rodzice o wewnętrznej lokalizacji kontroli rodzicielskiej będą bardziej skłonni do podejmowania działań terapeutycznych niż rodzice o zewnętrznym umiejscowieniu kontroli.

\section{Założenia badań własnych}

Główny problem badawczy dotyczył znaczenia umiejscowienia kontroli rodzicielskiej dla współpracy matek ze specjalistami w procesie wspomagania rozwoju dziecka. Założono, że matki o wyższym poziomie wewnętrznej lokalizacji kontroli będą charakteryzowały się lepszą współpracą ze specjalistami. Zmienną zależną stanowił więc poziom współpracy, a zmienną niezależną lokalizacja kontroli rodzicielskiej.

Postanowiono również określić, które z wybranych czynników społeczno-demograficznych różnicują poczucie kontroli u badanych matek. Założono, że istnieje zależność między lokalizacją kontroli rodzicielskiej matek a wybranymi zmiennymi społeczno-demograficznymi. Analizie poddano następujące zmienne niezależne: wiek i wykształcenie matek oraz wiek i płeć dzieci.

Badania zostały przeprowadzone przy wykorzystaniu metody sondażu diagnostycznego. Narzędzie badawcze stanowiła skala Parental Locus of Control, autorstwa Campis, Lyman i Prentice-Dunn (1986), we własnej adaptacji językowej. Narzędzie składa się z 47 stwierdzeń, podzielonych na pięć podskal, które dotyczą: skuteczności wychowawczej rodzica, odpowiedzialności rodzica za zachowanie dziecka, kontroli dziecka nad życiem rodzica, wiary rodziców w przeznaczenie czy przypadek oraz rodzicielskiej kontroli nad zachowaniem dziecka. Badani zaznaczają na pięciostopniowej skali Likerta, w jakim stopniu zgadzają się z daną tezą. Poszczególnym stwierdzeniom przyporządkowane zostały wartości liczbowe od jednego (zdecydowanie nie zgadzam się) do pięciu (zdecydowanie zgadzam się) lub od pięciu do jednego w przypadku twierdzeń o odwróconej punktacji. Wysokie wyniki świadczą o zewnętrznym poczuciu kontroli rodziców, natomiast niskie dowodzą wewnętrznego poczucia kontroli badanych.

\section{Charakterystyka badanej populacji}

W badaniu uczestniczyły 54 matki dzieci w wieku od dwóch do czterech lat $\mathrm{z}$ diagnozą opóźnienia rozwoju psychoruchowego $\left(\mathrm{R} 62.0^{1}\right)$, uczęszczających na zaję-

1 W Międzynarodowej Statystycznej Klasyfikacji Chorób i Problemów Zdrowotnych ICD-10, obowiązującej w służbie zdrowia, kodem tym oznaczone jest opóźnienie etapów rozwoju fizjologicznego (opóźnione chodzenie, mówienie). 
ciach terapeutycznych w Ośrodku Rehabilitacji Dziennej dla Dzieci w Rzeszowie. Wszystkie dzieci objęte badaniem posiadały orzeczenie o niepełnosprawności. Matki podzielone zostały na dwie grupy. Pierwszą grupę (Grupa A) stanowiły matki, które w opinii terapeutów podejmowały współpracę w procesie terapeutycznym. Relacje z nimi według zmodyfikowanego podziału Kawuli można określić jako partycypację lub akomodację. Do drugiej grupy (Grupa B) przydzielone zostały matki, które nawiązywały kontakt o typie inercji, czyli pozostawały bierne i nie angażowały się w proces terapii, ale systematycznie przyprowadzały dziecko na zajęcia. W badaniu nie brano pod uwagę osób, które pozostawały w opozycji, ponieważ najczęściej rezygnowały one z procesu terapeutycznego lub nie były zainteresowane udziałem w sondażu. Większość z badanych matek (34 osoby) mieszkała na wsi, a pozostałe osoby (20 matek) w mieście. Strukturę wieku badanych przedstawia tabela 1.

Tabela 1. Struktura wieku badanych matek

\begin{tabular}{|l|c|c|c|c|c|c|}
\hline \multirow{2}{*}{ Wiek } & \multicolumn{2}{|c|}{ Grupa A } & \multicolumn{2}{c|}{ Grupa B } & \multicolumn{2}{c|}{ Ogółem } \\
\cline { 2 - 7 } & $\mathbf{N}$ & proc. & N & proc. & N & proc. \\
\hline $\mathbf{2 0 - 3 0}$ & 13 & 48,2 & 15 & 55,6 & 28 & 51,8 \\
\hline $\mathbf{3 1 - 4 0}$ & 12 & 44,4 & 8 & 29,6 & 20 & 37,1 \\
\hline $\mathbf{4 1 - 5 0}$ & 2 & 7,4 & 4 & 14,8 & 6 & 11,1 \\
\hline Ogółem: & 27 & 100 & 27 & 100 & 54 & 100 \\
\hline
\end{tabular}

Źródło: opracowanie własne.

Jak wynika $\mathrm{z}$ analizy danych prezentowanych $\mathrm{w}$ tabeli największą grupę stanowią matki w przedziale wiekowym 20-30 lat (51,8 proc.), a najmniej liczną matki po 41 roku życia (11,1 proc.). Matki w przedziale wiekowym 31-40 lat stanowiły 37,1 proc. badanych.

Matki podejmujące współpracę i nieangażujące się w oddziaływania terapeutyczne różniły się pod względem wykształcenia. W grupie matek współpracujących przeważały osoby z wyższym wykształceniem (55,6 proc.), w drugiej grupie natomiast - matki z wykształceniem średnim (63 proc.). W grupie matek niepodejmujących współpracy wykształcenie wyższe miało 25,9 proc. badanych. Szczegółowy rozkład wyników przedstawia tabela 2. 
Tabela 2. Wykształcenie badanych matek

\begin{tabular}{|l|c|c|c|c|c|c|}
\hline \multirow{2}{*}{ Wykształcenie } & \multicolumn{2}{|c|}{ Grupa A } & \multicolumn{2}{c|}{ Grupa B } & \multicolumn{2}{c|}{ Ogółem } \\
\cline { 2 - 7 } & $\mathbf{N}$ & proc. & $\mathbf{N}$ & proc. & N & proc. \\
\hline Zawodowe & 2 & 7,4 & 3 & 11,1 & 5 & 9,3 \\
\hline Średnie & 10 & 37 & 17 & 63 & 27 & 50 \\
\hline Wyższe & 15 & 55,6 & 7 & 25,9 & 22 & 40,7 \\
\hline Ogółem: & 27 & 100 & 27 & 100 & 54 & 100 \\
\hline
\end{tabular}

Źródło: opracowanie własne.

W celu określenia, czy obie grupy różnią się pod względem lokalizacji kontroli rodzicielskiej, przeprowadzono analizy statystyczne. Po ustaleniu normalności rozkładu, przeprowadzono obliczenia za pomocą testu t-Student dla prób niezależnych. Przyjęto poziom istotności $\mathrm{p}<0,005$. Wyniki przedstawione zostały $\mathrm{w}$ tabeli 3.

Tabela 3. Zestawienie wyników PLOC w grupie matek współpracujących i niepodejmujących współpracy

\begin{tabular}{|l|c|c|c|c|c|}
\hline PLOC & $\begin{array}{c}\text { Średnia - } \\
\text { grupa A }\end{array}$ & $\begin{array}{c}\text { Średnia - } \\
\text { grupa B }\end{array}$ & T & df & p \\
\hline Ocena skuteczności & 19,92 & 27,66 & 5,47 & 52 & 0,000001 \\
\hline $\begin{array}{l}\text { Rodzicielska } \\
\text { odpowiedzialność }\end{array}$ & 23,77 & 24,48 & 0,47 & 52 & 0,635312 \\
\hline $\begin{array}{l}\text { Kontrola dziecka } \\
\text { nad rodzicami }\end{array}$ & 18 & 19,96 & 1,93 & 52 & 0,058864 \\
\hline $\begin{array}{l}\text { Przekonania } \\
\text { rodziców }\end{array}$ & 27,78 & 33,56 & 4,11 & 52 & 0,000138 \\
\hline $\begin{array}{l}\text { Kontrola rodziców } \\
\text { nad dzieckiem }\end{array}$ & 25,12 & 30,96 & 3,47 & 52 & 0,001031 \\
\hline Suma PLOC: & 114,59 & 136,62 & 3,67 & 52 & 0,000079 \\
\hline
\end{tabular}

Źródło: opracowanie własne.

Pierwszą z analizowanych podskal jest ocena własnej skuteczności rodzicielskiej. Wysokie wyniki w tej podskali świadczą o niskim poczuciu skuteczności wychowawczej; wskazują na rodziców, którzy nie czują się efektywni w swych rodzicielskich rolach i mają niskie poczucie kompetencji wychowawczych (Campis i in. 1986). Jak wykazała analiza uzyskanych wyników, matki, które podejmują współpracę ze specjalistami, charakteryzują się wyższym nasileniem poczucia skuteczności w procesie wychowawczym $(19,92)$ niż matki, które nie podejmują współpracy ze specjalistami $(27,66)$. Różnice pomiędzy grupami są istotne statystycznie $(t=5,47$, 
p < 0,001). Wyniki te korespondują z założeniami Alberta Bandury (2007) dotyczącymi poczucia własnej skuteczności. Jak twierdził Bandura, poczucie skuteczności motywuje ludzi do podejmowania działań, jeżeli natomiast nie jesteśmy pewni wyników własnych dążeń, to mamy większą skłonność do rezygnowania z celów, których osiągnięcia nie jesteśmy pewni. Wtedy rodzice mogą nie podejmować działań terapeutycznych, gdyż zakładają, że nie będą wystarczająco efektywni w działaniu.

Następną z analizowanych podskal była rodzicielska odpowiedzialność za zachowania dziecka. Wysokie wyniki na tej podskali uzyskują rodzice, którzy nie czują się odpowiedzialni za zachowania dziecka. Analiza danych uzyskanych w toku procesu badawczego pozwala stwierdzić, że matki z obu grup cechuje podobny poziom poczucia odpowiedzialności za zachowania dziecka. Matki z grupy A uzyskały średni wynik wynoszący 23,77 , natomiast matki z grupy B - wynik 24,48 , świadczący o nieco niższym poczuciu odpowiedzialności za zachowania dziecka. Analizy testem t-Studenta wykazały, że badane grupy nie różnią się w sposób istotny statystycznie.

Kolejna podskala określa stopień, w jakim dziecko poprzez swoje zachowania kontroluje życie rodziców. Wysokie wyniki uzyskują rodzice, którzy czują, że potrzeby i wymagania ich dziecka są ważniejsze od potrzeb rodzica i dominują nad funkcjonowaniem rodziny. Analiza danych wykazała, że matki współpracujące w procesie terapii uzyskały niższe wyniki w tej podskali (18), świadczące o mniejszej dominacji dziecka w życiu rodzinnym, niż matki niepodejmujące współpracy $(19,96)$. Różnice te nie są jednak istotne statystycznie.

Znaczące różnice pomiędzy badanymi grupami uwidaczniają się w podskali przekonań, która dotyczy wiary rodziców w przeznaczenie czy przypadek. Matki partycypujące w oddziaływaniach terapeutycznych osiągnęly znacznie niższą średnią $(27,78)$ niż matki, które charakteryzuje postawa bierności $(33,56)$, co świadczy o przewadze wewnętrznego poczucia kontroli u matek podejmujących współpracę. Wyniki te są istotne statystycznie $(\mathrm{t}=4,11 ; \mathrm{p}<0,001)$. Osoby, które osiągają wysokie wyniki na tej skali, są skłonne wierzyć, że proces wychowawczy i zachowania dziecka są zależne od zewnętrznych czynników, takich jak los, fatum czy inni ludzie. Mając takie przekonanie, osoby te mogą być niechętne do podejmowania działań terapeutycznych ze względu na brak poczucia sprawstwa. Jeżeli nie są przekonane o własnym wpływie na otoczenie, a przede wszystkim na zachowania dziecka, nie będą skłonne do współpracy w procesie terapii, gdyż przerzucają odpowiedzialność za ten proces na inne czynniki zewnętrzne.

Ostatnią $\mathrm{z}$ analizowanych podskal jest rodzicielska kontrola nad zachowaniem dziecka. Rodzice, którzy czują się niezdolni do kontrolowania zachowania własnego dziecka, uzyskują wyższe wyniki. Jak wykazały przeprowadzone analizy, matki, które współpracują $\mathrm{w}$ procesie terapeutycznym, uzyskały wyniki świadczące o wyższym nasileniu poczucia kontroli nad zachowaniem dziecka $(25,12)$, niż matki, które tej współpracy nie podejmowały $(30,96)$. Poczucie kontroli nad 
zachowaniami dziecka może być czynnikiem sprzyjającym aktywnej postawie w procesie rehabilitacji.

Ogólną ocenę lokalizacji kontroli rodzicielskiej uzyskano poprzez zsumowanie wyników z poszczególnych podskal. Badane grupy matek różniły się w sposób istotny statystycznie między sobą $(\mathrm{t}=3,67 ; \mathrm{p}<0,001)$. Matki współpracujące ze specjalistami osiągnęły niższe wyniki $(114,59)$, świadczące o większym nasileniu wewnętrznej lokalizacji kontroli od matek mających trudności w podejmowaniu tej współpracy $(136,62)$, które cechowały się większym nasileniem zewnętrznego umiejscowienia kontroli rodzicielskiej. Wyniki te pozwalają na potwierdzenie hipotezy zakładającej, że lokalizacja kontroli rodzicielskiej w rodzinach dzieci z opóźnieniem rozwoju psychoruchowego, objętych oddziaływaniami terapeutycznymi, różnicuje poziom współpracy ze specjalistami oferującymi wsparcie z zakresu wczesnej interwencji i wspomagania rozwoju dziecka.

Analizie podlegały również wybrane czynniki społeczno-demograficzne. Postanowiono sprawdzić, które z wybranych zmiennych różnicują umiejscowienie kontroli wychowawczej rodziców dzieci z opóźnieniem rozwoju psychoruchowego. Pod uwagę wzięto czynniki związane z matką - wiek i wykształcenie, oraz te związane z dzieckiem - wiek dziecka i jego płeć. Związki pomiędzy wybranymi zmiennymi zbadano za pomocą współczynnika korelacji r-Pearsona, a ich wyniki przedstawiono w tabeli 4 .

Tabela 4. Lokalizacja kontroli a wybrane zmienne społeczno-demograficzne

\begin{tabular}{|l|c|c|}
\hline Wybrane zmienne & $\begin{array}{c}\text { Współczynnik korelacji } \\
\text { r-Pearsona }\end{array}$ & Poziom istotności \\
\hline Wiek matki & 0,0703 & $\mathrm{p}=0,613$ \\
\hline Wykształcenie matki & $-0,2843$ & $\mathrm{p}=0,037$ \\
\hline Wiek dziecka & 0,0211 & $\mathrm{p}=0,879$ \\
\hline Płeć dziecka & 0,091 & $\mathrm{p}=0,513$ \\
\hline
\end{tabular}

Źródło: opracowanie własne.

Analizy korelacji nie wykazały istotnych statystycznie zależności pomiędzy poczuciem lokalizacji kontroli rodzicielskiej a wiekiem matki. Istotność statystyczna została potwierdzona w przypadku wykształcenia - im wyższe było wykształcenie matek, tym uzyskiwały one niższy wynik w skali PLOC, co świadczy o większym nasileniu wewnętrznego poczucia kontroli u matek posiadających wykształcenie wyższe niż u matek z wykształceniem średnim czy zawodowym ( $\mathrm{r}=-0,2843$; $\mathrm{p}=$ o,037). Podobne zależności pomiędzy lokalizacją kontroli a wykształceniem wykazały m.in. badania Barbary Szmigielskiej (1999) czy Krystyny Kurowskiej i Katarzyny Krakowieckiej (2014). Nie wykazano istotnych statystycznie zależności pomiędzy lokalizacją kontroli rodzicielskiej a wiekiem czy płcią dziecka. 


\section{Podsumowanie}

Wyniki przeprowadzonych badań pozwalają na stwierdzenie, że matki współpracujące w procesie terapii dzieci różnią się w sposób istotny statystycznie od rodziców niepodejmujących współpracy ze specjalistami pod względem umiejscowienia kontroli wychowawczej. Matki, których relacje z terapeutami można określić jako partycypację i akomodację, uzyskiwały znacznie niższe wyniki w skali PLOC, świadczące o wewnętrznym umiejscowieniu kontroli, w porównaniu z grupą matek, które cechowała inercja w relacjach ze specjalistami. Znaczącym czynnikiem różnicującym wynik PLOC było wykształcenie badanych. Wyższy poziom wykształcenia korespondował z wewnętrznym poczuciem kontroli wychowawczej.

Biorąc pod uwagę fakt, że lokalizacja kontroli kształtuje się w wyniku gromadzonych doświadczeń, w toku pracy z rodziną należy podjąć wysiłki mające na celu kształtowanie wewnętrznego poczucia kontroli w sytuacjach wychowawczych. Rodzice powinni mieć możliwość uczestniczenia w treningach i szkoleniach podnoszących ich kompetencje rodzicielskie i umiejętność radzenia sobie w sytuacjach wychowawczych z dzieckiem niepełnosprawnym.

Również w toku codziennych oddziaływań terapeutycznych należy aktywizować rodziców do działania i uczestnictwa w procesie terapeutycznym, stosując się do następujących zasad:

- rozpoczynanie od działań, które dają gwarancję osiągnięcia sukcesu i pozwolą rodzicom na dostrzeżenie własnej skuteczności w pracy z dzieckiem;

- rezygnacja z zadań, które nie są na miarę możliwości rodzica, a także tych, które nie będą służyły nawiązywaniu bliskiej relacji z dzieckiem;

- w relacji z rodzicami należy stosować wzmocnienia pozytywne, zauważając najmniejsze nawet efekty ich pracy z dzieckiem, a czasami tylko zaangażowanie w działania;

- metody pracy należy dobierać indywidualnie do potrzeb i możliwość rodziny, po dokonaniu wnikliwej diagnozy.

\section{Bibliografia}

Bandura A. (2007). Teoria społecznego uczenia się. Warszawa: PWN.

Campis L. K., Lyman R. D. i Prentice-Dunn S. (1986). The parenting locus of control scale: Development and validation. „Journal of Clinical Child Psychology”, nr 15, s. 260-267.

Freed R. D., Tompson R. C. (2011). Predictors of Parental Locus of Control in Mothers Pre- and Early Adolescent. „Journal of Clinical Child and Adolescent Psychology”, nr 40 (1), s. 100-110.

Hassall R., Rose J., McDonald J. (2005). Parenting stress in mothers of children with an intellectual disability: the effects of parental cognitions in relations to child 
characteristic and family suport. "Journal of Intellectual Disability Research", nr 49 (6), s. 405-418.

Józefik B. (2012). Terapia rodzin. W: Namysłowska I. (red.). Psychiatria dzieci i młodzieży. Warszawa: PZWL.

Kawula S., Brągiel J., Janke A. W. (1997). Pedagogika rodziny. Toruń: Adam Marszałek.

Kielin J. (2003). Jak pracować z rodzicami dziecka upośledzonego? Gdańsk: GWP. Kościelska M. (1998). Oblicza upośledzenia. Warszawa: PWN

Kurowska K., Krakowiecka K. (2014). Zachowania zdrowotne a umiejscowienie kontroli zdrowia u osób po przebytym udarze mózgu. „Geriatria”, nr 8, s. 13-21. Lew-Koralewicz A. (2013). Rola rodziny w terapii dzieci z zaburzeniami rozwoju w opiniach rodziców i terapeutów. W: Baran J., Gunia G. (red.). Teoria i praktyka oddziaływań profilaktyczno-wspierających rozwój osób z niepetnosprawnością. Kraków: Impuls.

Okoń W. (2001). Nowy słownik pedagogiczny. Warszawa: Żak.

Orwid M. (2012). Czynniki psychospołeczne w psychiatrii dzieci i młodzieży. W: Namysłowska I. (red.). Psychiatria dzieci i młodzieży. Warszawa: PZWL. Pervin L. A. (2002). Psychologia osobowości. Gdańsk: GWP.

Poznaniak W. (200o). Teorie uczenia sie społecznego jako model normalnego i zaburzonego funkcjonowania jednostki oraz grupy. W: Sęk H. (red.). Społeczna psychologia kliniczna. Warszawa: PWN.

Seligman M. (1999). Childhood Disability and the Family. W: Schwean V. L. Saklofske D.H. Handbook of psychosocial characteristics of exceptional children. NY: Springer Science.

Szmigielska B. (1999). Społeczno-uczeniowa teoria osobowości Juliana B. Rottera. W: Gałdowa A. (red.). Klasyczne i współczesne koncepcje osobowości. Kraków: Wyd. UJ.

Tavris C., Wade C. (1999). Psychologia Podejścia i koncepcje. Poznań: Zysk i S-ka. Twardowski A. (2012). Wczesne wspomaganie rozwoju dzieci z niepetnosprawnościami w środowisku rodzinnym. Poznań: Wydawnictwo Naukowe UAM.

\section{PARENTAL LOCUS OF CONTROL IN MOTHERS AND THEIR COOPERATION WITH SPECIALISTS IN THE PROCESS OF THERAPY OF CHILDREN WITH DEVELOPMENTAL DISABILITIES}

\footnotetext{
Abstract: The purpose of this study was to answer the question concerning the parental locus of control in mothers whose children suffer from developmental disabilities, and more precisely, to discuss the cases of mothers who cooperated with specialists in the early intervention process, and those who had difficulty with undertaking the necessary rehabilitation. The research shows that mothers who found it difficult to cooperate with
} 
therapists display greater tendency to be more externally oriented in their locus of control than mothers who collaborate with specialists and engage in the early intervention process.

Keywords: parental locus of control, cooperation of parents and therapist, developmental disabilities.

Aneta Lew-Koralewicz - doktor nauk społecznych w zakresie pedagogiki, zatrudniona na stanowisku adiunkta w Zakładzie Pedagogiki Specjalnej Wydziału Pedagogicznego Uniwersytetu Rzeszowskiego. Autorka monografii: Zachowania trudne małych dzieci z zaburzeniami rozwoju - uwarunkowania profilaktyka i terapia (w druku) oraz publikacji z zakresu terapii dzieci z niepełnosprawnością. Zainteresowania naukowe: wczesna interwencja i wczesne wspomaganie rozwoju, problematyka zaburzeń ze spektrum autyzmu, zachowania trudne u osób z zaburzeniami rozwoju, stosowana analiza zachowania. Adres e-mailowy: aneta.lew@interia.pl. 